\author{
Hussain A Obaidi \\ BDS, MSc (Prof) \\ Manar Y Abdul-Qadir \\ BDS, MSc (Assist Lect)
}

\section{The Mandibular Dimension Changes Among Four Age Groups}

\author{
Dept of Pedod, orthod, and Prev Dentistry \\ College of Dentistry, University of Mosul
}

\begin{abstract}
.
Aims: the study was planned to assess the value of the change among four pubertal age groups of Class l occlusion. Materials and Methods: The sample subjects were comprise of the flowing groups: 11yeas(23 males\&25 females), 12years(19 males \&22 females), 13years(22 males \&28 females) and 14 years(22 males \&22 females). Each individual radiographed with cephalometric film. The cephalometric films traced and the mandibular lengths ( Ar-Pog, \& Go-Gn \& Ar-Go) were measured. The data subjected to the descriptive and variance statistics at 0.05 significant level. Results: The findings disclosed that the mandibular lengths (Ar-Pog, Go-Gn \&Ar-Go) were significantly greater value at 14 years age group as compared with $11,12, \& 13$ years age groups. The sex variation appeared insignificant change among the four age groups for the mandibular lengths. Conclusion: The increase mandibular length at age 14 years can be regarded in relive the crowding at 11,12, \&13 years age groups for both sexes.

Key words: Mandibular change; cephalometric radiograph.
\end{abstract}

Obaidi HA, Abdul-Qadir MY. The Mandibular Dimension Changes Among Four Age Groups. AlRafidain Dent J. 2007; 7(SpIss): 109S-113S

Received: $12 / 11 / 2006 \quad$ Sent to Referees: $14 / 11 / 2006$

Accepted for Publication: 10/4/2007

\section{INTRODUCTION}

The majority of treatment is directed toward pre and post-adolescent patients. these individuals are still undergoing significant changes in their occlusion, facial skeleton and profile. Such changes are quite complex because each person has a unique growth pattern that influenced by their particular genetic makeup ${ }^{(1)}$. The mandible grows significantly more than the maxilla during adolescence making the skeletal profile less convex with growth ${ }^{(2)}$ .The increase in mandibular length continue to the early forties ${ }^{(3)}$. The largest incremental growth in craniofacial structures was found in the mandible in both sexes ${ }^{(4)}$. Ochoa and Nanda ${ }^{(5)}$ reported that male have more incremental growth and duration of growth of mandible than female, the females showed relative slow growth of mandible until 14 years of age whereas males continue to grow significantly until age 16 years.This made the male facial profiles straighter as they grow older, while female profile remain more convex.
The aims of this study designed to reveal the value of change of the mandibular lengths(Ar-Pog, GO-Gn \&Ar-Gn) among the pubertal age groups .

\section{MATERIALS AND METHODS}

The individuals involved in this study were selected from intermediate and primary schools in the center of Mosul City. The sample included: Age 11 years (23 males \& 25 females), age 12 years (19 males \& 22 females), age 13 years (22 males \& 28 females), age 14 years(22 males \& 22 females).

The criteria for the samples selection were full complement of permanent teeth excluding the third molars and normal occlusion with bilateral class I molar and canine relationships ${ }^{(6)}$, normal over-jet and over bite $(1-4 \mathrm{~mm})^{(7)}$, no detectable crowding and rotations, no apparent facial disharmony, and no previous orthodontic treatment or maxillofacial surgery. Subjects at 11 years of age were selected on the basis of presence of Class I molar re- 
lationship with normal over-jet and overbite $^{(8)}$.

Each subject was radiographed with lateral cephalometric film the films were traced. After tracing of the cephalometric radiographs, the following parameters were measured (figure 1):
1. Ar-Pog: Represents the total length of the mandible ${ }^{(9)}$.

2. Go-Gn: Represents the length of mandibular corpus ${ }^{(10)}$.

3. Ar-Go: Represents the height of mandibular $^{(11)}$.

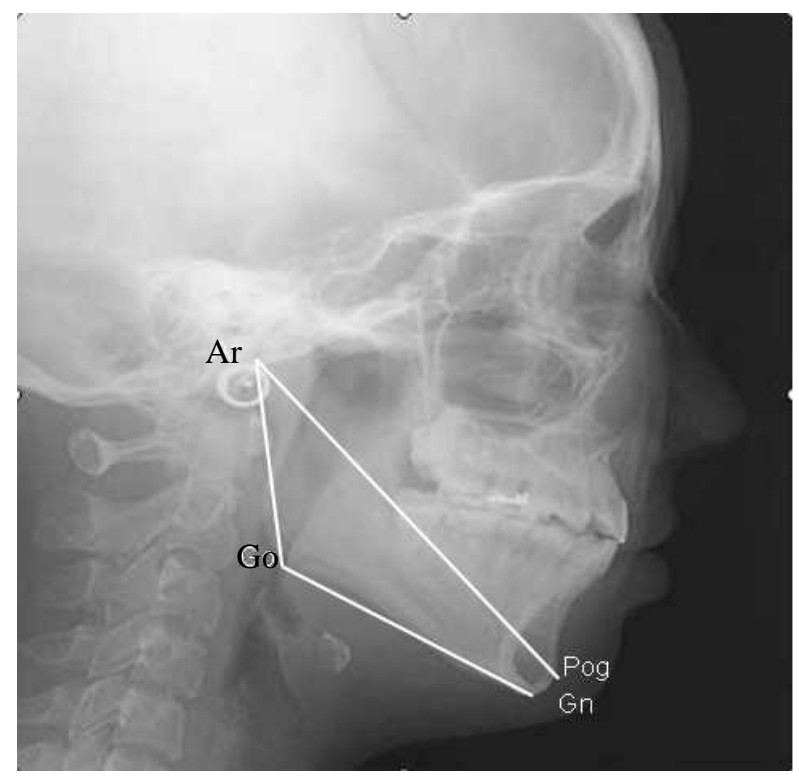

Figure(1):Demonstrates the mandibular dimensions

\section{RESULTS}

The descriptive statistics for the skeletal mandibular dimensions(Table 1) showed that the (Ar-Pog), (Go-Gn) and (Ar-Go) greater mean value at 14 years age group in sexes. At 14 years age group, the males appeared larger mean value than females for the (Ar-Pog and Ar-Go) whereas the females disclosed more mean value for the(Go-Gn). The age variation for the skeletal mandibular dimensions at 0.05 significant difference (Table 2-4) demonstrated that the Ar-Pog, Go-Gn \&Ar-Gn significantly greater mean value at 14 years group as compared with 11 years groups for both sexes. The sex variation for the mandibular dimensions showed insignificant differences at the four age groups at 0.05 significant level.

\section{DISCUSSION}

The total mandibular length (ArPog) and mandibular corpus length (GoGn) showed higher values with increasing age group with significantly higher value noticed at 14 years group as compared to both 11 years and 12 years groups. These findings indicate increasing mandibular length and body length with increasing age and are consistent with the findings of Ochoa and Nanda ${ }^{(5)}$ who reported significant increase in Ar-Pog from 10 to 12 years and from 12 to 14 years in males. The present findings regarding Go-Gn dimension come in agreement with those of Nanda ${ }^{(10)}$ who demonstrated a continuous increase in Go-Gn from 10 to 14 years in males In females, both Ar-Pog and GoGn distances showed higher values with increasing age group with significantly higher value noticed at 14 years group as compared to both 11 years and 12 years groups indicating an increase in mandibular length and body length with increasing age. This coincides with the findings of Nanda ${ }^{(9)}$ who reported increased mandibular length from 11 to 14 years in females. Similar findings of increased Go-Gn distance were reported by $\mathrm{Nanda}^{(10)}$ and Lewis et al. ${ }^{(12)}$ for males from 11 to 14 
years. According to Harris ${ }^{(13)}$ the increase in mandibular length occurs as a result of growth in three main sites, the condyles, remodeling of the ramus by appositional activity on the posterior border complemented by resorption on the anterior border and deposition along the inferior margin of the body of mandible Comparison between males and females demonstrated no significant difference between the sexes. Males however, showed larger values than females for both Ar-Pog and Go$\mathrm{Gn}$ distances in the four age groups except for Go-Gn at 12 years group where females displayed higher value than males by $0.06 \mathrm{~mm}$. The general pattern indicates larger mandibular length and body length in males than in females. Similar findings regarding Ar-Pog length were reported by Ochoa and Nanda ${ }^{(5)}$ who showed larger values in males than in females at 10,12 and 14 years. Regarding mandibular body length, the present findings disagree with Al-Baiati ${ }^{(14)}$ who reported greater values in females than in males at 11 and 14 years. This difference between the findings of present study and those of Al-Baiati may be attributed to the different variable used by Al-Baiati (used Go-Me to measure mandibular body length).

Table (1): Descriptive statistics and t-test for the skeletal mandibular dimensions of males and females

\begin{tabular}{|c|c|c|c|c|c|c|c|c|c|}
\hline Age & Variable & Sex & No. & Mean & $+\mathrm{SD}$ & Min & Max & t-test & $p$ value \\
\hline \multirow{6}{*}{ 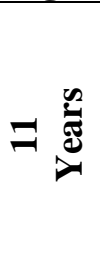 } & \multirow{2}{*}{ Ar-Pog* } & Male & 23 & 104.54 & $\overline{4.27}$ & 97.5 & 112 & \multirow{2}{*}{1.06} & \multirow{2}{*}{0.29} \\
\hline & & Female & 25 & 103.34 & 3.56 & 96 & 113 & & \\
\hline & \multirow{2}{*}{ Go-Gn* } & Male & 23 & 75.63 & 3.28 & 67 & 82 & \multirow{2}{*}{1.23} & \multirow{2}{*}{0.23} \\
\hline & & Female & 25 & 74.38 & 3.73 & 66 & 82 & & \\
\hline & \multirow{2}{*}{$\mathrm{Ar}-\mathrm{Go} *$} & Male & 23 & 41.89 & 3.08 & 33 & 46 & \multirow{2}{*}{-0.28} & \multirow{2}{*}{0.78} \\
\hline & & Female & 25 & 42.14 & 3.16 & 37 & 48 & & \\
\hline \multirow{6}{*}{$\approx \underset{\nu}{\beth}$} & \multirow{2}{*}{ Ar-Pog* } & Male & 19 & 106.66 & 4.72 & 98.5 & 117 & \multirow{2}{*}{0.10} & \multirow{2}{*}{0.92} \\
\hline & & Female & 22 & 106.52 & 4.01 & 99.5 & 115 & & \\
\hline & \multirow{2}{*}{ Go-Gn* } & Male & 19 & 75.71 & 3.50 & 70.5 & 81 & \multirow{2}{*}{-0.06} & \multirow{2}{*}{0.95} \\
\hline & & Female & 22 & 75.77 & 3.24 & 70 & 83.5 & & \\
\hline & \multirow{2}{*}{$\mathrm{Ar}-\mathrm{Go}^{*}$} & Male & 19 & 44.16 & 3.72 & 39 & 50 & \multirow{2}{*}{-0.36} & \multirow{2}{*}{0.72} \\
\hline & & Female & 22 & 44.55 & 3.25 & 39.5 & 50 & & \\
\hline \multirow{6}{*}{$\leadsto \underset{\beth}{\mathscr{J}}$} & \multirow{2}{*}{ Ar-Pog* } & Male & 19 & 106.66 & 4.72 & 98.5 & 117 & \multirow{2}{*}{0.98} & \multirow{2}{*}{0.33} \\
\hline & & Female & 22 & 106.52 & 4.01 & 99.5 & 115 & & \\
\hline & \multirow{2}{*}{ Go-Gn* } & Male & 19 & 75.71 & 3.50 & 70.5 & 81 & \multirow{2}{*}{1.24} & \multirow{2}{*}{0.22} \\
\hline & & Female & 22 & 75.77 & 3.24 & 70 & 83.5 & & \\
\hline & \multirow{2}{*}{$\mathrm{Ar}-\mathrm{Go}^{*}$} & Male & 19 & 44.16 & 3.72 & 39 & 50 & \multirow{2}{*}{-1.43} & \multirow{2}{*}{0.16} \\
\hline & & Female & 22 & 44.55 & 3.25 & 39.5 & 50 & & \\
\hline \multirow{6}{*}{ 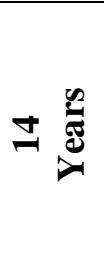 } & \multirow{2}{*}{ Ar-Pog* } & Male & 22 & 111.66 & 5.58 & 104 & 122.5 & 024 & 081 \\
\hline & & Female & 22 & 111.30 & 4.48 & 103 & 122 & & 0.81 \\
\hline & Go- & Male & 22 & 79.89 & 4.10 & 72.5 & 87 & 0.3 & 0 \\
\hline & $\mathrm{GO}-\mathrm{G}$ & Female & 22 & 79.64 & 3.19 & 74 & 87 & 0.23 & 0.82 \\
\hline & $\mathrm{Ar}-\mathrm{Go}^{*}$ & Male & 22 & 47.61 & 4.89 & 38.5 & 59 & 031 & 075 \\
\hline & & Female & 22 & 47.18 & 4.20 & 40 & 56 & 0.31 & \\
\hline
\end{tabular}

*Measurements in mm; SD: Standard deviation; Min: Minimum; Max: Maximum. 
Table (2): Analysis of Duncan's Test of Ar-Pog for the four age groups

\begin{tabular}{|c|c|c|c|c|c|}
\hline Sex & Age Group & No. & Mean & \pm SD & Significancy* \\
\hline \multirow{4}{*}{$\frac{0}{\sum^{\pi}}$} & 11 Years & 23 & 104.540 & 4.270 & A \\
\hline & 12 Years & 19 & 106.660 & 4.720 & $A B$ \\
\hline & 13 Years & 22 & 109.930 & 3.390 & $\mathrm{BC}$ \\
\hline & 14 Years & 22 & 111.660 & 5.580 & C \\
\hline \multirow{4}{*}{ 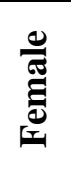 } & 11 Years & 25 & 103.340 & 3.560 & $\mathrm{a}$ \\
\hline & 12 Years & 22 & 106.520 & 4.010 & $a b$ \\
\hline & 13 Years & 28 & 108.790 & 4.570 & bc \\
\hline & 14 Years & 22 & 111.300 & 4.480 & c \\
\hline
\end{tabular}

For males: $\mathrm{F}$-value $=10.98 ; \mathrm{p}$-value $=0.000 ; \mathrm{S}(\mathrm{p} \leq 0.05)$

For females: $\mathrm{F}-$ value $=15.57$; $\mathrm{p}$-value $=0.000 ; \mathrm{S}(\mathrm{p} \leq 0.05)$.

* Means with the same letters were statistically not significant.

Table (3): Analysis of Duncan's Test of Go-Gn for the four age groups

\begin{tabular}{|c|c|c|c|c|c|}
\hline Sex & Age Group & No. & Mean & + SD & Significancy * \\
\hline \multirow{4}{*}{$\frac{0}{\sum^{\pi}}$} & 11 Years & 23 & 75.630 & 3.276 & $\bar{A}$ \\
\hline & 12 Years & 19 & 75.711 & 3.497 & A \\
\hline & 13 Years & 22 & 78.886 & 3.552 & B \\
\hline & 14 Years & 22 & 79.886 & 4.097 & B \\
\hline \multirow{4}{*}{ 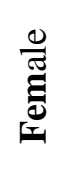 } & 11 Years & 25 & 74.380 & 3.728 & $\mathrm{a}$ \\
\hline & 12 Years & 22 & 75.773 & 3.243 & $a b$ \\
\hline & 13 Years & 28 & 77.554 & 3.959 & bc \\
\hline & 14 Years & 22 & 79.636 & 3.193 & C \\
\hline
\end{tabular}

For males: $\mathrm{F}$-value $=7.85 ; p$-value $=0.000 ; \mathrm{S}(p \leq 0.05)$.

For females: $\mathrm{F}$-value $=9.43 ; p$-value $=0.000 ; \mathrm{S}(p \leq 0.05)$.

* Means with the same letters were statistically not significant

Table (4): Analysis of Duncan's Test of Ar-Go for the four age groups

\begin{tabular}{|c|c|c|c|c|c|}
\hline Sex & Age Group & No. & Mean & $\underline{+S D}$ & Significancy * \\
\hline \multirow{4}{*}{$\frac{\stackrel{0}{\pi}}{\sum}$} & 11 Years & 23 & 41.891 & 3.082 & $\mathrm{~A}$ \\
\hline & 12 Years & 19 & 44.158 & 3.716 & A \\
\hline & 13 Years & 22 & 44.727 & 3.734 & $\mathrm{AB}$ \\
\hline & 14 Years & 22 & 47.614 & 4.889 & $\mathrm{~B}$ \\
\hline \multirow{4}{*}{ 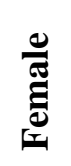 } & 11 Years & 25 & 42.140 & 3.157 & a \\
\hline & 12 Years & 22 & 44.545 & 3.251 & $a b$ \\
\hline & 13 Years & 28 & 46.143 & 3.240 & b \\
\hline & 14 Years & 22 & 47.182 & 4.199 & b \\
\hline
\end{tabular}

For males: $\mathrm{F}$-value $=8.13 ; p$-value $=0.000 ; \mathrm{S}(p \leq 0.05)$.

For females: $\mathrm{F}-$ value $=9.74 ; p-$ value $=0.000 ; \mathrm{S}(p \leq 0.05)$.

* Means with the same letters were statistically not significant.

Ramus (Ar-Go) height showed higher values with increasing age group in males with significantly higher value noticed at 14 years group as compared to both 11 years and 12 years groups indicating an increase in ramus height with increasing age. The present findings come in agree- ment with those of Bishara et al. ${ }^{(15)}$ for males between 10 and 15 year Females also showed higher mean dimensions of Ar-Go with increasing age group with significant difference noticed between 14 years group and 11 years group. Similar findings were reported by Bishara et al. ${ }^{(15)}$ 
for females between 10 and 15 years. The increase in ramus height occurs in response to endochondral replacement at the condyle accompanied by surface remodeling as stated by Proffit ${ }^{(16)}$.

Comparison between male and female subjects revealed no significant difference between the sexes with females showing larger mean dimensions than males in 11 years, 12 years and 13 years groups, and this came in agreement with the findings of Lewis et al. ${ }^{(12)}$ where they reported that females continue to show greater values than males from 7 to 15 ye-ars. However, at 14 years group, the results of this study showed a larger value in males than in females. This difference in the results may be attributed to the ethnic variation.

\section{CONCLUTIONS}

The study demonstrated no significant sex variation in the mandibular parameters (Ar-Pog, Go-Gn and (Ar-Go) for the age groups. Whereas; the mandibular parameters disclose increase significantly between 11years and 14 years age groups.

\section{REFERANCES}

1. Bishara SE. Facial and dental changes in adolescents and their clinical implications. Angle Orthod. 2000; 70(6): 471483.

2. Lundstrom F, Leighton BC, Richardson A, Lundstrom A. A proportional analysis of some facial height and depth variables in 10 to 16 years old children. Eur J Orthod. 1998; 20; 35-44.

3. Formby WA, Nanda RS, Currier GF. Longitudinal changes in adult facial profile. Am J Orthod Dentofac Orthop. 1994; 105(5): 464-476.

4. Ibrahim Yavus, Ikbal A, Saydas B, Ceylan I. Longitudinal postero-anterior changes in transverse and vertical craniofacial structures between 10 and 14 years of age. Angle Orthod. 2004; 74(5): 624-629.

5. Ochoa BK, Nanda RS. Comparison of maxillary and mandibular growth. Am J Orthod Dentofac Orthop. 2004, 125(2):
148-159.

6. Bishara SE, Jackobsen JR, Hession TJ, Treder JE. Soft tissue profile changes from 5-45 years of age. Am J Orthod Dentofac Orthop. 1998, 114(6):698706.

7. Ruksujarit T, Ratanyatikul C, Godfrey K, Deesamur S. Lateral. cephalometric no-rms for 12-14 years Thai girls and boys in Khon Kaen with an acceptable profile. Khon Kaen Univ Dent J. 2001; 6(1): 76-83.

8. Nanda RS, Meng H, Kapila S, Goorhuis J. Growth changes in the soft tissue facial profile. Angle Orthod. 1990; 60(3): 177-190.

9. Nanda SK. Differential growth of the female face in the anteroposterior dimension. Angle Orthod.1992; 62(1): 2334.

10. 10.Nanda RS. The rat of growth of several facial components measured from serial cephalometric roentgwnograms. Am J Orthod. 1955; 41:658-673.

11. Love RJ, Murray JM, Mamandras AH. Facial growth in males 16-20 years of age. Am J Orthod Dentofac Othop.1990; 97(3): 200-206.

12. Lewis AB, Roche AF, Wagner $B$. Growth of the mandible during pubescence. Angle Orthod.1982; 52(4): 325342.

13. Harris JE. A cephalometric analysis of mandibular growth rate. Am J Othod.1962; 48(3): 161-174.

14. Al-Baiati AH. Dentofacial growth pattern of Iraqi children sample: A longitudinal cephalometric study. MSc. Thesis. College of Dentistry, University of Baghdad.1992.

15. Bishara SE, Peterson LC, Bishara E. Changes in facial dimensions and relationships between the ages of 5 and 25 years. Am J Orthod.1984; 85(3): 238252.

16. Proffit WR. Contemporary Orthodontics. $3^{\text {rd }}$ ed. Mosby.2000; Pp: 30, 40-42, 161, 171. 